\title{
Antioxidant and free radical scavenging potential of Citrullus colocynthis (L.) Schrad. methanolic fruit extract
}

\author{
SUNIL KUMAR ${ }^{1}$ \\ DINESH KUMAR \\ MANJUSHA $^{1}$ \\ KAMAL SAROHA \\ NIDHAN SINGH ${ }^{2}$ \\ BHOODEV VASHISHTA ${ }^{2}$ \\ ${ }^{1}$ Department of Pharmaceutical \\ Sciences, Kurukshetra University \\ Kurukshetra-136119 Haryana, India \\ ${ }^{2}$ Department of Botany, Kurukshetra \\ University, Kurukshetra-136119 \\ Haryana, India
}

\begin{abstract}
Citrullus colocynthis (L.) Schrad. (Cucurbitaceae) is a medicinal plant traditionally used as an abortifacient and to treat constipation, oedema, bacterial infections, cancer and diabetes. Preliminary phytochemical screening of the plant showed the presence of large amounts of phenolics and flavonoids. Subsequent quantification showed the presence of $0.74 \%(\mathrm{~m} / \mathrm{m})$ phenolics (calculated as gallic acid) and $0.13 \%(\mathrm{~m} / \mathrm{m})$ flavonoids calculated as catechin equivalents per $100 \mathrm{~g}$ of fresh mass. The presence of phenolic compounds prompted us to evaluate its antioxidant activity. In the present study, methanolic fruit extract of $C$. colocynthis was screened to evaluate its free-radical scavenging effect. The highest antioxidant and free radical scavenging ability of the fruit extract was observed at a concentration of $2500 \mu \mathrm{g} \mathrm{mL}^{-1}$.
\end{abstract}

Keywords: Citrullus colocynthis fruit, Cucurbitaceae, methanolic extract, antioxidants, free radical scavenging

Reactive oxygen species (ROS) such as superoxide anions, hydrogen peroxide and hydroxyl, nitric oxide radicals, play an important role in oxidative stress related to the pathogenesis of various important diseases $(1,2)$. Antioxidants act as a major defense against radical mediated toxicity by protecting the damages caused by free radicals. Antioxidant-based drugs/formulations for the prevention and treatment of complex diseases, like atherosclerosis, stroke, diabetes, Alzheimer's disease and cancer, have appeared in the last three decades (3). This has attracted a great deal of research interest in natural antioxidants. Flavonoids and phenolic compounds are widely distributed in plants which have been reported to exert multiple biological effects, including antioxidant, free radical scavenging abilities, anti-inflammatory, anticarcinogenic, etc. (4). The aim of the present investigation was to evaluate in vitro antioxidant and free radical scavenging activity of the Citrullus colocynthis fruit extract. The fruits of Citrullus colocynthis, commonly known as bitter apple, are bitter, acrid, cooling, cathartic, carminative, antipyretic, anthelmintic and are useful in hypoglycemia, tumors, ascites, leucoderma, ulcers, asthma, bronchitis, urethorrhea, jaundice, dyspepsia, constipation, elephantiasis and splenomegaly (5). Fruit extract exhibits nematicidal properties.

* Correspondence, e-mail: sunilmadhuban@yahoo.com 
S Kumar et al.: Antioxidant and free radical scavenging potential of Citrullus colocynthis (L.) Schrad. methanolic fruit extract, Acta Pharm. 58 (2008) 215-220.

\section{MATERIALS AND METHODS}

\section{Chemicals}

Chemicals used in this study were 1,1-diphenyl-2-picrylhydrazyl (DPPH) obtained from Sigma-Aldrich, India, NADH and sulfanilamide obtained from Himedia, Laboratories Pvt. Ltd., India, Folin-Ciocalteu reagent, potassium ferricyanide and sodium nitroprusside obtained from Qualigens Fine Chemicals, Glaxo Smithkline Pharmaceutical Ltd., India, naphthylethylenediamine dihydrochloride, $N$-1-naphthylethylenediamine dihydrochloride, sodium nitrite, trichloroacetic acid, butylated hydroxy anisole (BHA), ascorbic acid, $\alpha$-tocopheryl acetate, ethylenediamine tetraacetic acid, phosphoric acid, nitro blue tetrazolium, phenazine methosulfate, ferrous ammonium sulfate, DMSO are obtained from Sd Fine Chemicals Ltd, India. All reagents used in the study were of analytical grade.

\section{Plant material}

Citrullus colocynthis (Cucurbitaceae) fruits were collected from the areas near the Rewari district, Haryana, India, during October, 2006 and authenticated at the Department of Botany, Kurukshetra University, Kurukshetra, Haryana, India. The fruits were cleaned and dried in the shade, then powdered to $0.422 \mathrm{~mm}$ mesh size and stored in an airtight container at $25^{\circ} \mathrm{C}$.

\section{Extraction}

Citrullus colocynthis fruits $(100 \mathrm{~g})$ in powdered form were extracted with methanol using a Soxhlet assembly for $48 \mathrm{~h}$, filtered and last traces of the solvent were evaporated under reduced pressure in a rotary evaporator. The yield was $2.78 \mathrm{~g}$ of dry extract.

\section{Total phenolic content}

The total phenolic content of Citrullus colocynthis fruit (CCF) extract was determined spectrometrically (6). Folin-Ciocalteu's reagent, $1 \mathrm{~mL}$ previously diluted with $20 \mathrm{~mL}$ distilled water, was added to $1 \mathrm{~mL}$ of sample $\left(250 \mu \mathrm{g} \mathrm{mL}^{-1}\right)$ and mixed thoroughly. To the mixture, $4 \mathrm{~mL}$ of sodium carbonate $\left(75 \mathrm{~g} \mathrm{~L}^{-1}\right)$ and $10 \mathrm{~mL}$ of water were added and mixed well. The mixture was allowed to stand for $2 \mathrm{~h}$ at room temperature. Contents were then centrifuged at $2000 \times g$ for $5 \mathrm{~min}$ and the absorbance of the supernatant was taken at 760 $\mathrm{nm}$ using a double beam spectrophotometer 2202 (Systronics, India).

A standard curve was obtained using various concentrations of gallic acid. Results were expressed as percentage of gallic acid equivalents (GAE) per $100 \mathrm{~g}$ fresh mass.

\section{Total flavonoid assay}

Total flavonoid contents were measured with the aluminum chloride colorimetric assay (7). Methanolic fruit extracts or standard solution of catechin $\left(500 \mu \mathrm{g} \mathrm{mL}^{-1}\right)$ was added to $10 \mathrm{~mL}$ volumetric flask containing $4 \mathrm{~mL}$ of water. To the above mixture, $0.3 \mathrm{~mL}$ of $5 \% \mathrm{NaNO}_{2}$ was added. After 5 minutes, $0.3 \mathrm{~mL}$ of $10 \% \mathrm{AlCl}_{3}$ was added. After $6 \mathrm{~min}$, 
$2 \mathrm{~mL}$ of $1 \mathrm{~mol} \mathrm{~L}^{-1} \mathrm{NaOH}$ was added and the total volume was made up to $10 \mathrm{~mL}$ with water. The solution was mixed well and the absorbance was measured against a prepared reagent blank at $510 \mathrm{~nm}$. Total flavonoid content of the fruit was expressed as percentage of catechin equivalent per $100 \mathrm{~g}$ fresh mass.

\section{$D P P H$ free radical scavenging activity}

The free-radical scavenging activity of CCF extract was measured by the decrease in absorbance of methanolic solution of DPPH (8). A stock solution of DPPH (33 mg L-1) was prepared in methanol and $5 \mathrm{~mL}$ of this stock solution was added to $1 \mathrm{~mL}$ of the CCF extract solution at different concentrations $\left(250,500,1000,1500,2000\right.$ and $\left.2500 \mu \mathrm{g} \mathrm{mL}^{-1}\right)$. After $30 \mathrm{~min}$, absorbance was measured at $517 \mathrm{~nm}$ and compared with the standards, i.e., ascorbic acid, BHA and $\alpha$-tocopherol $(10-50 \mu \mathrm{g} \mathrm{mL}-1)$. Scavenging activity was expressed as the percentage inhibition.

\section{Hydroxyl radical scavenging activity}

Methanolic extract at different concentrations was placed in a test tube and evaporated to dryness. One $\mathrm{mL}$ of iron-EDTA solution $(0.13 \%$ ferrous ammonium sulfate and $0.26 \%$ EDTA), $0.5 \mathrm{~mL}$ of $0.018 \%$ EDTA, $1 \mathrm{~mL}$ of DMSO [0.85\%, $V / V$, in $0.1 \mathrm{~mol} \mathrm{~L}^{-1}$ phosphate buffer, $\mathrm{pH} 7.4 \mathrm{]}$ and $0.5 \mathrm{~mL}$ of $0.22 \%$ ascorbic acid were added to each tube (9). The tubes were capped tightly and heated in a water bath at $80-90{ }^{\circ} \mathrm{C}$ for $15 \mathrm{~min}$. The reaction was terminated by adding $1 \mathrm{~mL}$ of ice-cold TCA $(17.5 \% \mathrm{~m} / \mathrm{V})$. Three $\mathrm{ml}$ of Nash reagent (75.0 g ammonium acetate, $3 \mathrm{~mL}$ glacial acetic acid and $2 \mathrm{~mL}$ acetyl acetone were mixed and water was added to a total volume of $1 \mathrm{~L}$ ) was added to each tube; the tubes were left at room temperature for $15 \mathrm{~min}$ for colour development. The intensity of the yellow colour formed was measured at $412 \mathrm{~nm}$ against a blank of the reagent. Percentage inhibition was determined by comparing the results of the test and standard compounds.

\section{Scavenging of hydrogen peroxide}

A solution of hydrogen peroxide $\left(40 \mathrm{mmol} \mathrm{L}^{-1}\right)$ was prepared in phosphate buffer ( $\mathrm{pH}$ 7.4). Different concentrations $(250-2500 \mu \mathrm{g} \mathrm{mL}-1$ ) of CCF were added to the hydrogen peroxide solution $(40 \mathrm{mmol} \mathrm{L}-1,0.6 \mathrm{~mL})$. Absorbance of hydrogen peroxide at 230 $\mathrm{nm}$ was determined after $10 \mathrm{~min}$ against a blank solution containing phosphate buffer without hydrogen peroxide (10). Percentage scavenging of hydrogen peroxide of the CCF extract and standard compounds was calculated.

\section{Superoxide radical scavenging assay}

The reaction mixture consisting of $1 \mathrm{~mL}$ of nitro blue tetrazolium (NBT) solution (156 mmol L-1 NBT in phosphate buffer, $\mathrm{pH} 7.4), 1 \mathrm{~mL}$ NADH solution (468 mmol L-1 $\mathrm{NADH}$ in phosphate buffer, $\mathrm{pH} 7.4$ ), and $1 \mathrm{~mL}$ of sample solution of CCF extract was mixed. The reaction was started by adding $100 \mathrm{~mL}$ of phenazine methosulfate (PMS) solution (60 $\mathrm{mmol} \mathrm{L}^{-1}$ PMS in phosphate buffer, $\mathrm{pH} 7.4$ ) to the mixture. The reaction mixture was incubated at $25{ }^{\circ} \mathrm{C}$ for $5 \mathrm{~min}$ and the absorbance was measured at $560 \mathrm{~nm}$ 
against blank sample and compared with the standards $(10,11)$. Decreased absorbance of the reaction mixture indicated increased superoxide anion scavenging activity. The percentage inhibition of superoxide anion generation was calculated.

\section{Nitric oxide scavenging activity}

Nitric oxide scavenging activity was measured spectrophotometrically (12). Sodium nitroprusside $\left(5 \mathrm{mmol} \mathrm{L}^{-1}\right)$ in phosphate buffered saline $\mathrm{pH} 7.4$, was mixed with different concentrations of the extract $\left(250-2500 \mu \mathrm{g} \mathrm{mL}^{-1}\right)$ prepared in methanol and incubated at $25^{\circ} \mathrm{C}$ for $30 \mathrm{~min}$. A control without the test compound, but with an equivalent amount of methanol, was taken. After $30 \mathrm{~min}, 1.5 \mathrm{~mL}$ of the incubated solution was removed and diluted with $1.5 \mathrm{~mL}$ of Griess reagent (1\% sulphanilamide, $2 \%$ phosphoric acid and $0.1 \% \mathrm{~N}$-1-naphthylethylenediamine dihydrochloride). Absorbance of the chromophore formed during diazotization of the nitrite with sulphanilamide and subsequent coupling with $\mathrm{N}$-1-naphthylethylene diamine dihydrochloride was measured at $546 \mathrm{~nm}$ and the percentage scavenging activity was measured with reference to the standard.

\section{Statistical analysis}

Values were represented as mean \pm SD of three parallel measurements and data were analyzed using the $t$-test.

\section{RESULTS AND DISCUSSION}

From the results on the total phenolic content, it was found that there was $0.74 \%$ of gallic acid equivalents of phenolic compounds while the total flavonoid content was $0.13 \%$ of catechin equivalent of fresh mass of C. colocynthis fruit extract. The results of antioxidant and free radical scavenging activity are given in Table I.

The free radical scavenging activity was evaluated by using various in vitro assays. DPPH radical was used as a substrate to evaluate the free radical scavenging activity of CCF extract. The scavenging effect of CCF extract on the DPPH radical was $88.0 \pm 2.7 \%$ $(p<0.005)$, at a concentration of $2500 \mu \mathrm{g} \mathrm{mL}^{-1}$ compared to the scavenging effects of ascorbic acid, BHA and $\alpha$-tocopherol at $50 \mu \mathrm{g} \mathrm{mL}^{-1}$ of $89.5 \pm 1.1,83.2 \pm 1.1$ and $67.5 \pm 0.8 \%$ $(p<0.05)$ respectively.

Hydroxyl radicals are the major active oxygen species that cause lipid oxidation and enormous biological damage (13). The percentage of hydroxyl radical scavenging increased with the increasing concentration of fruit extract. The percentage of $\mathrm{H}_{2} \mathrm{O}_{2}$ scavenging activity of CCF was found to be $62.7 \pm 3.5(p<0.001)$ at $2500 \mu \mathrm{g} \mathrm{mL} \mathrm{m}^{-1}$, and antioxidant activity of BHA and $\alpha$-tocopherol was $89.3 \pm 3.1 \%(p<0.05)$ and and $94.5 \pm 2.5 \%$ $(p<0.05)$, respectively at a concentration of $50 \mu \mathrm{g} \mathrm{mL}-1 . \mathrm{H}_{2} \mathrm{O}_{2}$ itself is not very reactive, but it can sometimes be toxic to the cell because it may give rise to hydroxyl radical in the cells. Thus, removal of $\mathrm{H}_{2} \mathrm{O}_{2}$ is very important for protection of food systems.

The superoxide anion radical scavenging activity of CCF was assayed using the PMS-NADH system. The percentage inhibition of superoxide generation by CCF at 2500 
S Kumar et al.: Antioxidant and free radical scavenging potential of Citrullus colocynthis (L.) Schrad. methanolic fruit extract, Acta Pharm. 58 (2008) 215-220.

$\mu \mathrm{g} \mathrm{mL} \mathrm{m}^{-1}$ concentration was found to be $71.3 \pm 3.2 \%(p<0.005)$. On the other hand, ascorbic acid, BHA and $\alpha$-tocopherol at $50 \mu \mathrm{g} \mathrm{mL}^{-1}$ exerted $85.6 \pm 2.5,68.0 \pm 4.6$ and $74.5 \pm 2.7 \%$ $(p<0.05)$ inhibition of the superoxide radical.

Nitric oxide (NO) is a potent pleiotropic mediator of physiological processes such as smooth muscle relaxation, neuronal signaling, inhibition of platelet aggregation and

Table I. Antioxidant profile of the Citrullus colocynthis fruit extract ${ }^{a}$

\begin{tabular}{lcccccc}
\hline Sample & $\begin{array}{c}\text { Conc. } \\
(\mu \mathrm{g} \\
\left.\mathrm{mL}^{-1}\right)\end{array}$ & $\begin{array}{c}\text { DPPH } \\
\text { radical } \\
\text { scaven- } \\
\text { ging (\%) }\end{array}$ & $\begin{array}{c}\text { Hydroxyl } \\
\text { radical sca- } \\
\text { venging (\%) }\end{array}$ & $\begin{array}{c}\text { Hydrogen } \\
\text { peroxide sca- } \\
\text { venging (\%) }\end{array}$ & $\begin{array}{c}\text { Superoxide } \\
\text { anion sca- } \\
\text { venging }(\%)\end{array}$ & $\begin{array}{c}\text { Nitric oxide } \\
\text { scavenging } \\
(\%)\end{array}$ \\
\hline CCF & $(2500)$ & $88.0 \pm 2.7$ & $71.4 \pm 3.2$ & $62.7 \pm 3.5$ & $71.3 \pm 3.2$ & $61.4 \pm 3.8$ \\
Ascorbic acid & $(50)$ & $89.5 \pm 1.1$ & - & - & $85.7 \pm 2.5$ & $86.0 \pm 3.5$ \\
BHA & $(50)$ & $83.2 \pm 1.1$ & $83.2 \pm 3.2$ & $89.3 \pm 3.1$ & $68.0 \pm 4.6$ & \\
$\alpha$-Tocopherol & $(50)$ & $67.5 \pm 0.8$ & - & $94.5 \pm 2.5$ & $74.5 \pm 2.7$ & \\
\hline
\end{tabular}

${ }^{\text {a }}$ Mean $\pm \mathrm{SD}, n=3$.

regulation of cell mediated toxicity (14). The percentage inhibition of nitric oxide generation by CCF at $2500 \mu \mathrm{g} \mathrm{mL}^{-1}$ concentration was found to be $61.4 \pm 3.8 \%(p<0.005)$. On the other hand, ascorbic acid at $50 \mu \mathrm{g} \mathrm{mL}^{-1}$ concentration showed $86.0 \pm 3.5 \%(p<0.05)$ inhibition of nitric oxide.

\section{CONCLUSIONS}

Free radical scavenging effect of CCF increases with increasing concentration and maximum antioxidant activity was observed at $2500 \mu \mathrm{g} \mathrm{mL}^{-1}$. Antioxidant activity may be due to phenolic compounds in CCF but further work should be done on the isolation and identification of other antioxidant components of Citrullus colocynthis.

\section{REFERENCES}

1. B. Halliwell and J. M. C. Gutteridge, Free Radicals in Biology and Medicine, $3^{\text {rd }}$ ed., Oxford University Press, Oxford 1999.

2. T. Finkel and N. J. Holbrook, Oxidants, oxidative stress and the biology of aging, Nature 408 (2000) 239-247; DOI:10.1038/35041687.

3. T. P. A. Devasagayam, J. C. Tilak, K. K. Boloor, K. S. Sane, S. S. Ghaskadbi and R. D. Lele, Review: Free radicals and antioxidants in human health: Current status and future prospects, J. Assoc. Phys. India 52 (2004) 794-804.

4. A. L. Miller, Antioxidant flavonoids: structure, function and clinical usage, Alt. Med. Rev. 1 (1996) 103-111. 
5. A. Delazar, S. Gibbons, A. R. Kosari, H. Nazemiyeh, M. Modarresi, L. Nahar and S. D. Sarker, Flavone C-glycosides and cucurbitacin glycosides from Citrullus colocynthis, DARU 14 (2006) 109-114.

6. V. L. Singleton and J. A. Rossi, Colorimetry of total phenolics with phosphomolybdic phosphotungstic acid reagents, Am. J. Enol. Vitic. 16 (1965) 144-158.

7. D. Marinova, F. Ribarova and M. Atanasova, Total phenolics and flavonoids in Bulgarian fruits and vegetables, J. Univ. Chem. Tech. Metall. 40 (2005) 255-260.

8. N. Sreejayan and M. N. A. Rao, Free radical scavenging activity of curcuminoids, Drug Res. 46 (1996) 169-171.

9. S. M. Klein, G. Cohen and A. I. Cederbaum, Production of formaldehyde during metabolism of dimethylsulphoxide by hydroxyl radical generating system, Biochemistry 20 (1981) 6006-6012.

10. I. Gülçin, H. A. Alici and M. Cesur, Determination of in vitro antioxidant and radical scavenging activities of propofol, Chem. Pharm. Bull. 53 (2005) 281-285; DOI: 10.1248/cpb.53.281.

11. M. Nishikimi, N. A. Rao and K. Yagi, The occurrence of superoxide anion in the reaction of reduced phenazine methosulfate and molecular oxygen, Biochem. Biophys. Res. Commun. 46 (1972) 849-853.

12. R. Govindarajan, S. Rastogi, M. Vijayakumar, A. Shirwaikar, A. K. Rawat, S. Mehrotra and P. Pushpangadan, Studies on antioxidant activities of Desmodium gangeticum, Biol. Pharm. Bull. 26 (2003) 1424-1427; DOI: 10.1248/bpd.26.1424.

13. L. W. Aurand, N. H. Boonme and G. G. Gidding, Superoxide and singlet oxygen in milk lipid peroxidation, J. Dairy Sci. 60 (1977) 363-369.

14. A. E. Hagerman, K. M. Riedl, G. A. Jones, K. N. Sovik, N. T. Ritchard, P. W. Hartzfeld and T. L. Riechel, High molecular weight plant polyphenolics (tannins) as biological antioxidants, J. $A g$ ric. Food Chem. 46 (1998) 1887-1892; DOI: 10.1021/jf970975b.

\section{$S A \check{Z} E T A K$}

\section{Antioksidativni potencijal i sposobnost hvatanja slobodnih radikala metanolnog ekstrakta plodova Citrullus colocynthis (L.) Schrad.}

SUNIL KUMAR, DINESH KUMAR, MANJUSHA, KAMAL SAROHA, NIDHAN SINGH i BHOODEV VASHISHTA

Citrullus colocynthis (L.) Schrad. (Cucurbitaceae) je ljekovita biljka koja se tradicionalno upotrebljava kao abortiv i za liječenje konstipacije, edema, bakterijskih infekcija, karcinoma i dijabetesa. Preliminarno fitokemijsko pretraživanje ukazalo je na prisutnost velikih količina fenola i flavonoida. Udio fenola bio je $0,74 \%$ (preračunato na galnu kiseli$\mathrm{nu}$ ), a flavonoida $0,13 \%$ preračunato na ekvivalente katehina na $100 \mathrm{~g}$ svježe mase. Zbog prisutnosti fenolnih spojeva ispitivano je antioksidativno djelovanje i sposobnost hvatanja slobodnih radikala metanolnog ekstrakta plodova. Koncentracija $2500 \mu \mathrm{g} \mathrm{mL}^{-1}$ imala je najjači učinak.

Ključne riječi: plod biljke Citrullus colocynthis (Cucurbitaceae), metanolni ekstrakt, antioksidansi, hvatanje slobodnih radikala

Department of Pharmaceutical Sciences, Kurukshetra University, Kurukshetra-136119, Haryana, India

Department of Botany, Kurukshetra University, Kurukshetra-136119, Haryana, India 